\title{
Surfacing Authentic Leadership: Inspiration from After Life
}

\author{
Jon Billsberry \\ Professor of Management \\ Deakin University \\ j.billsberry@deakin.edu.au \\ Andrea North-Samardzic \\ Lecturer in Organizational Behavior \\ Deakin University \\ andreans@deakin.edu.au
}

\begin{abstract}
This paper advocates an innovative approach to help leadership students analyze, capture, and remember the nature of their authentic leadership. This developmental activity was inspired by the Japanese film, Wandâfuru raifu (After Life) (Kore-Eda, Sato, $\&$ Shigenobu, 1998), in which the recently deceased are asked to recall and relate a memory that symbolizes all that is important to them. After this memory is replayed to them the recently deceased move on to the afterlife and keep the memory prominent in their minds for eternity. This activity is applied to authentic leadership by asking leadership students to recall their family, personal, and work histories as they relate to their leadership. To bring this activity up to date and into the real world, the students are asked to tell their story directly to a camera in front of a green screen. In postproduction, images related to the students' stories are keyed in to replace the green screen thereby creating powerful memories of the factors influencing the students' authentic leadership. This new technique is proposed as an integrative and memorable activity that captures and synthesizes insights from other authentic leadership exercises while focusing on the actionable lessons. Viewing of the film prior to the teaching event offers the additional benefit of creating an atmosphere of quiet contemplation and reflection in students' minds.
\end{abstract}

\section{Introduction}

Authentic leadership is one of the newest leadership theories to have emerged and gained widespread interest including chapters in leadership textbooks (e.g., Northouse, 2016; Roe, 2014; Zehndorfer, 2013), research centers (e.g., Centre for Creative and Authentic Leadership at Australian Catholic University), and coverage in the popular press (e.g., Anon., 2015; Beddoes-Jones, 2012; Hill, 2012). Its emergence is, in large part, a reaction to the corporate scandals of the early years of the $21^{\text {st }}$ century when business school-trained CEOs were caught engaging in unethical practices (Avolio \& Gardner, 2005; Kelly, 2013). In addition, it is also a reaction to the shallow and insincere management-speak that seems to have become the norm with leaders in the $21^{\text {st }}$ century (Alvesson \& Spicer, 2011). Authentic leaders are those who are true to their own values, 
who can be trusted, and who are open in their communication with others (Sparrowe, 2005).

Authentic leadership is still in its infancy as a leadership theory (Shamir \& Eilam, 2005). As such, scholars are currently engaged in defining it, discovering its antecedents, and exploring its impact in real world settings. Nevertheless, its appeal is strong with students keen to explore its relevance to their own situations (Nyberg \& Sveningsson, 2014). Due to the newness of the topic, little work has been published that develop ways to incorporate authentic leadership into leadership development. The purpose of this paper is to address this gap and to outline a new approach inspired by the Japanese film, Wandâfuru raifu (After Life) (Kore-Eda, Sato, \& Shigenobu, 1998), which puts the surfacing, analysis, and learning from personal life stories center stage in helping people wishing to become authentic leaders become aware of the factors influencing the way they lead.

The paper begins with a review of authentic leadership that defines the concept and highlights critical issues related to the development of authentic leadership. Following this, the paper outlines some of the qualities that a teaching strategy might be expected to possess if it is to help people become authentic leaders. The paper ends with a description and discussion of a new teaching program to develop authentic leaders that adds an integrative activity to draw together lessons from more established techniques for surfacing leader's authenticity.

\section{Authentic Leadership}

There has been much writing on the subject of authentic leadership since it emerged as a significant topic of inquiry just over a decade ago (e.g., Avolio, 2013; Avolio \& Reichard, 2008; Nichols and Erakovich, 2013; Shamir \& Eilam, 2005; Walumbwa, Avolio, Gardner, Wernsing, \& Peterson, 2008). One of the central themes has focused on discovering the precise nature of authentic leadership. Sadly this stream of research has made only faltering progress due to the lack of a coherent definition as well as lack of distinction from other leadership theories (Northouse, 2016; Yukl, 2010). As a result, there are numerous conceptualizations; nevertheless, definitions have converged around some key themes.

Put simply, authentic leadership is an approach to leadership based on building relationships with followers based on trust, openness, and honesty (Walumbwa et al., 2008). To make this possible, scholars argue that to be authentic, leaders must have an awareness of their values, history, strengths, weaknesses, and goals (Bass \& Steidlmeier, 1999; George, 2003; Kouzes \& Posner, 2002; Luthans \& Avolio, 2003). They must also share their thoughts and beliefs openly and without wanton or unnecessary displays of emotion. They should be fair-minded and understand the ethical and moral base upon which they make decisions (Walumbwa et al., 2008).

A common viewpoint is that authenticity is a root concept that underlies the 
positive aspects of charismatic, transformational, spiritual, and ethical leadership theories (Avolio, 2013; Gardner et al., 2011; May et al., 2003; Yukl, 2010). Authentic leadership is generally associated with positivity, advocating positive psychological capabilities, and ethical climates (May, et al., 2003). As such, an authentic leader is not just authentically him or herself, but has an authentic self that is grounded in ethical and moral conduct. Gardner et al. (2005), and later Walumbwa et al. (2008), identify specific self-referent attributes of authentic leaders such as confidence, optimism, hope and resilience, strong moral character, high standards and values, advanced cognitive and emotional development, and optimal self-esteem.

Where authentic leadership departs somewhat from more traditional notions of leadership is that it emphasizes being true to oneself and one's value system rather than to a cause or a more abstract value system (Avolio \& Gardner, 2005; Kernis, 2003; Luthans $\&$ Avolio, 2003). This self-referent focus suggests that authentic leaders possess a higher self-concept than other more traditional forms of leaders, meaning that they "hold strongly held values and convictions and a stable sense of self-knowledge" (Shamar \& Eilam, 2005: 398). For Bass and Steidlmeier (1999), authenticity is an extension of transformational leadership with the leader acting as a moral agent in contrast to transformational leadership, which is essentially inauthentic, i.e., the desire to transform followers is for instrumental purposes instead of legitimately pursuing a higher moral order. This does not mean that an authentic leader is self-interested, but rather that an inauthentic leader can also transform followers (Nichols \& Erakovich, 2013).

Additionally, an authentic leader is one that serves to promote authentic followership (Avolio \& Reichard, 2008; Gardner et al., 2005). Leroy, Anseel, Gardner, and Sels' (2012) empirical study on authentic followership in the workplace points to the difference in followers under transformational leadership versus authentic leadership; transformational leaders empower followers to be become leaders whereas authentic leaders empower followers to be themselves.

As such, authentic leadership is argued to offer individual, team, and organizational benefits that other leadership approaches do not. Followers of authentic leaders reportedly have greater trust in leadership (Avolio et al., 2004; Gardner et al., 2005; Wong \& Cummings, 2009), higher levels of organizational commitment (Avolio et al., 2004; Jensen \& Luthans, 2006; Walumbwa et al., 2008) and citizenship behavior (Cottrill, Lopez, \& Hoffman, 2014), greater feelings of empowerment (Leroy, Palanski, \& Simons, 2012; Walumbwa, Wang, Wang, Schaubroeck, \& Avolio, 2010), leading to job satisfaction (Giallonardo et al., 2010; Walumbwa et al., 2008), higher levels of individual performance (Gardner et al., 2005; Leroy, Anseel, Gardner, \& Sels, 2012; Walumbwa et al., 2008) and well-being (Kernis, 2003; Wong \& Cummings, 2009). There is also evidence of authentic leadership leading to positive team outcomes (Hannah, Walumbwa, \& Fry, 2011; Wong \& Cummings, 2009) as well as firm financial performance (Clapp-Smith et al., 2009); however, it must be noted that the relationship between authentic leadership and firm financial performance is mediated by trust in the manager (Clapp-Smith et al., 2009). 
While there are numerous studies promoting the benefits of authentic leadership, it is not without criticism as an area of study. For a number of scholars the concept of authentic leadership is more useful in theory than in practice. For example, Costas and Taheri (2012) question whether the authentic leader presents as unrealistic fantasy figure that encourages greater dependency on the leader rather than empowerment and emancipation from the traditional leader-follower relationship. Algera and Lips-Wiersma (2012), who raise similar concerns about the utility of authentic leadership in action, agree with this arguing that expecting 24/7 authenticity from people in the workplace is not just unrealistic, but impractical. They also question why authenticity has been inextricably linked to ethical conduct given that one can be authentically imperfect. Indeed, recent research does not show a relationship between moral reasoning, authentic leadership, and moral action (Sendjaya, Pekerti, Hartel, Hirst, \& Butarbutar, 2014). Suppressing one's weaknesses in order to aspire to the inherently positive authentic fantasy figure can also have damaging consequences for both leaders and followers (Ford \& Harding, 2011). Even though acknowledging weakness can enhance perceptions of authenticity (Diddams \& Chang, 2012), whether such weaknesses are compatible with leadership is an avenue for further investigation.

Additional areas of consideration include not just examining the antecedents of authentic leadership (Gardner, Cogliser, Davis, \& Dickens, 2011; Peus, Wesche, Streicher, Braun, \& Frey, 2012), but also the study of factors outside the individual that give rise to authentic leadership. The level of analysis is strongly oriented to the individual leader and essentially abstracts the leader and follower from context and history (Gardiner, 2011). If a leader is not being authentic, it is assumed that this is the fault of the leader rather than organizational forces influencing behavior. Weischer, Weibler, and Petersen (2013) illustrate that how a leader enacts his or her true self for followers is key for perceptions of authenticity; how the social environment influences his or her behavior is not a factor. This ignores both the followers and the process of leadership. Given that a key part of authentic leadership is creating authentic followers (Gardner et al., 2005; Leroy et al., 2012), lack of attention to factors outside of the individual is an oversight of much authentic leadership research to date.

\section{Discovering Authenticity}

What is also lacking, and where this paper seeks to make a contribution, is interest in how authentic leadership is developed and taught, or, more accurately, how students can be helped to discover the roots of and the values underlying their own approach to leadership. As notions of authenticity are highly individual (Kernis, 2003), teaching it as a cohesive body of knowledge is challenging. Indeed, as Cooper, Scandura, and Schriesheim (2005: 483) stated a decade ago, "authentic leadership is not like other areas of leadership for which competency sets might be acquired in traditional training programs" p. 483). However, they did put forward four components that should form the basis on any program on authentic leadership: (a) the program should be genuine; (b) trigger events should be replicated during training; (c) determine whether ethics can be taught within the program; and (d) finally who are suitable participants (Cooper et al., 2005). Yet, it appears that little has been done in the way of developing such a program. 
However, the life stories approach of Shamir and Eilam (2005) addresses these four components.

Eliciting the story of the leader, and also the follower, is proving to be a useful way to explore the nebulous concept of authenticity. Indeed, Shamir and Eilam (2005) argue that the construction of the life-story is a major element in the development of authentic leaders. To help leaders develop a heightened sense of self-concept and moral awareness, self-reflection via storytelling provides a rich and detailed way to reveal the roots of someone's authenticity and approach to leadership (Hibbert, 2013). Storytelling can also impact on the follower. Weischer and colleagues' (2013) illustrated that telling one's life story can influence perceptions of authenticity. Storytelling is, therefore, incorporated into our new approach to surface the roots and values comprising people's authentic leadership.

Eliciting life stories is the most commonly advocated teaching approach in the literature. Sparrowe (2005) says that, "programs and interventions designed to increase self-awareness would be enhanced by autobiographical work, such as writing one's story, keeping journals, or even writing one's obituary (p. 436)." What is needed, therefore, is a way for students to reflect and capture their life stories with a focus on the influences, events, and decisions that shaped them as leaders today. This requires a method that can be tailored to the individual, helps them introspect and reveal critical incidents, and which is memorable.

With authentic leadership, the self-reflection to reveal such influences is likely to be traumatic, especially as negative influences are likely to be recalled, lengthy, and requiring many triggers to provide different lenses for introspection. It seems unlikely that such processes can work effectively in short and separate developmental sessions where the introspection is occurring away from supportive facilitators. Indeed, the development of a "safe" environment is crucial if students are to discover, reveal, and discuss their personal influences (Dempsey, Halton, \& Murphy, 2001; Ely, Ibarra, \& Kolb, 2011; Petriglieri, Wood, \& Petriglieri, 2011).

\section{A New Approach}

The primary learning goal is to help students become self-aware about the factors influencing their ability to perform as an authentic leader so that they can self-regulate their leadership behavior. In short, we want them to understand themselves better. This requires them to introspect deeply to reveal their values and the factors that made them so important to them, to think deeply about their moral and ethical stance and how this is realized in their actions, and to explore their leadership goals. As mentioned above, there exists a range of separate and freestanding techniques that can used to help students introspect on the influences of their behavior. These include tracing life histories (Kompf, 1993), individual rich pictures (Bell \& Morse, 2013; Bronte-Stewart, 1999; Rich \& Blake, 1994), questionnaires and inventories (Northouse, 2016), discussion of existential readings (Lawler, 2005), cognitive mapping (Calori, Johnson, \& Sarnin, 1994), projective techniques (Taylor \& Ladkin, 2009), obituary writing (Sparrowe, 2005), and poetry (Van 
Buskirk \& London, 2008; 2012). The plan is use many of these techniques in a weeklong residential setting using an integrative device that gathers together the lessons and produces a memorable artifact to assist in embedding the learning. The residential unit will be an elective in the overarching course meaning that participants opt into it if it accords with their needs and interests.

The starting point for the development of an integrative device that would address these issues came from a chance viewing of a Japanese film called Wandâfuru raifu. Literally translated as Wonderful Life, but realized in English-speaking territories as After Life (Kore-Eda, Sato, \& Shigenobu, 1998), this film portrays a development activity in a supportive and safe environment not unlike a spiritual retreat or a residential school.

Wandâfuru raifu imagines a way station that the recently departed must travel through to get from the living world to the afterlife. Most of the arrivals are somewhat disoriented and unsure that they are dead, or of the purpose of the way station. They are individually interviewed by one or two people who tell them that they are there to help them make the transition to the afterlife. They are told that in the next three days they must sift through their memories and find one moment that defines their life. At the end of the week, the "staff" of the way station re-enact this memory for them and, once they have viewed it, they transition to the afterlife and re-live the memory for eternity.

The atmosphere at the way station is intriguing. It is a tranquil place for contemplation, a supportive environment where consultations with the staff happen regularly and when people need them. These are caring people whose sole purpose is to help people introspect and discover their lives' defining moments such as a man remembering the breeze on a tram ride just before his summer vacation, or an elderly woman who remembers dancing for her older brother's friends. When a young girl recalls a Disneyland ride, a sympathetic counselor gently gets her to think about the other aspects of her life that she might value more.

The plan is to adopt this method as an integrative device, adapt it to modern sensibilities, and to bring it into the real world. It is envisaged being run as a weeklong residential school that encourages self-awareness as a leader. Copies of the film on DVD will be mailed to students several weeks before the school and they will be asked to view it before arriving. This activity will not only prepare students for the type of activities they can expect at the residential school, we hope that it will also help establish the ambience and introspective nature of the gathering that we hope to achieve. An alternative strategy of showing the film, or parts of it, at the event is not only too late for establishing the feel of the school, but it will run into copyright issues in many territories (Champoux \& Billsberry, 2012).

At the start of the residential school, after introductions, students will be informed that they will undertake a series of standalone activities for the purpose of revealing the roots of their beliefs and values that contribute to the ways in which they display their authenticity to others and an overarching activity, the one based on Wandâfuru raifu, to bring the lessons together. After three days of introspective activities (e.g., discussion of 
existentialist readings, writing one's own obituary, mindfulness activities, writing poems on relevant topics, rich picture drawing of hopes for the future, life history drawing, reflective interviews, and Tai Chi or other meditative approaches), students will be required to give a video-recorded verbal presentation that (a) recalls their family and personal history as it relates to their leadership, (b) describes incidents and events that have most shaped their values or leadership behavior, (c) explains how they would like to be remembered as a leader, and (d) discusses how the lessons they have learnt about themselves will influence the next big decision that they have to make.

Whereas in the film, the way station staff employ amateur dramatics to recreate people's memories, it is intended this will be brought up to date by having students talk directly to the camera (with the aid of a teleprompter if requested) in front of a green screen. Appropriate images, both moving and still, will be keyed into the background to create the ambience of the memories being described. The finished video would be played back to the students at the end of the week. Unlike the film, it is not possible to dispatch the student into the afterlife with the replayed memory fresh in their minds (not legally at any rate), and it would not seem advisable to do the analogous action of sending them home directly. These are likely to be quite powerful videos requiring considerable debriefing. Interestingly, it is not clear whether the screenings of the films should be private or shown to the whole group. We would hope that the low student numbers and bonding activities throughout the week would create a supportive atmosphere of sharing allowing the videos to be screened to the whole group in a plenary session with the students providing support, encouragement, and understanding to supplement input from the facilitators. However, we are conscious that we must closely monitor participants' emerging reactions during the week and have a fallback plan of individual screenings if the plenary screening is too confronting for anyone. Informal monitoring will be facilitated through the low student/tutor ratio and high level of contact through the days, and formally through individual daily one-to-one interviews. In addition, we are aware of the need to have both male and female facilitators at the event and the contact details of the university's student counselors. Also, we plan to hold pre-screening interviews with all prospective students to prepare them for nature of the event and to advise away any who might be expected to react adversely to the course.

There is an operational issue to overcome with regard to how the introspective videos are edited and embellished. On other leadership units we run, we have students create their own videos sometimes using green screen technology. With today's technology, keying in backgrounds is not particularly difficult or troublesome when using iMovie or similar software. However, the whole editing process is a lengthy process and the new teaching approach we have outlined in this paper is not about developing filmmaking skills, but about using this technology for introspection and surfacing of the roots of participants' authentic leadership. As such, we do not wish to devote significant student time to the physical production of the videos. Instead, we want students concentrating on the content. To accommodate this, we will employ professional editors to work with the recorded recollections to create a polished final product with suitable backgrounds and smooth edits. The cost of his approach will vary by territory, but a ballpark figure for this editing work in Australia is approximately $\$ 1500$ per editor per 
week. The cost of materials for a green-screen studio with background, stand, and LED lights is approximately $\$ 2000$, depending greatly on the quality of materials bought. Microphones, stand, tripod, and a suitable camera will probably be between $\$ 2000$ and $\$ 4000$.

\section{Conclusion}

In this paper, we have outlined a new integrative activity that should help people who want to be authentic leaders gather together insights about the roots of, and values underlying, their authentic leadership and thereby develop a deeper personal selfawareness, critical insights into their psychological and philosophical selves, and a clearer direction for the future. By necessity, this new activity must be psychologically invasive if it is to work. To reduce the risks and to tackle any that arise, we believe that four courses of action are necessary. First, students will need to be pre-screened to remove anyone who has a psychological history that might be expected to react poorly to the introspective activities. Second, a lot of effort will need to be invested in creating a safe and supportive environment where participants feel able to express themselves, listen actively to others, and help when needed. Third, there will be both male and female facilitators at the event and they will be experienced in running such introspective activities. Fourth, students will need to be provided with the contact details of the university's counseling service and encouraged to call them if they want to talk to someone and the facilitators are not present. We have reiterated this point here to emphasize that this is not a risk-free teaching option and that appropriate precautions must be taken.

Such risks are perhaps inevitable in the search for authenticity. Revelations from the past, missed opportunities, bad decisions, and life-changing moments are the currency we are dealing in. If we allow students to delve sufficiently deeply into themselves they may be able to produce meaningful and lasting insights that will help them emerge as authentic leaders. Moreover, the video artifacts that students produce during the integrative activity can be taken away and viewed whenever they wish to remind themselves of and reinforce the lessons. 


\section{References}

Algera, P. M., \& Lips-Wiersma, M. (2012). Radical authentic leadership: Co-creating the conditions under which all members of the organization can be authentic. The Leadership Quarterly, 23(1), 118-131.

Alvesson, M., \& Spicer, A. (2011). Metaphors We Lead By: Understanding Leadership in the Real World. London: Routledge.

Anon. (2015). Authenticity - Is It Enough? Vancouver Sun, 8 January. Downloaded from http://blogs.vancouversun.com/2015/01/08/authenticity-is-it-enough/ on 12 January 2015.

Avolio, B. J., \& Gardner, W. L. (2005). Authentic leadership development: Getting to the root of positive forms of leadership. The Leadership Quarterly, 16(3), 315-338.

Avolio, B. J., Gardner, W. L., Walumbwa, F. O., Luthans, F., \& May, D. R. (2004). Unlocking the mask: A look at the process by which authentic leaders impact follower attitudes and behaviors. The Leadership Quarterly, 15(6), 801-823.

Avolio, B. J., \& Reichard, R. J. (2008). The rise of authentic followership. In R. E. Riggio, I. Chaleff, \& J. Lipman-Blumen (eds.). The Art of Followership: How Great Followers Create Great Leaders and Organizations, pp. 325-337. San Francisco: Jossey-Bass.

Bass, B. M., \& Steidlmeier, P. (1999). Ethics, character, and authentic transformational leadership behavior. The Leadership Quarterly, 10(2), 181-217.

Beddoes-Jones, F. (2012). Authentic leadership: The key to building trust. People Management, August, 44-47.

Bell, S., \& Morse, S. (2013). Rich pictures: a means to explore the 'sustainable mind'? Sustainable Development, 21(1), 30-47.

Bronte-Stewart, M. (1999). Regarding rich pictures as tools for communication in information systems development. Computing and Information Systems, 6(1), 85104.

Calori, R., Johnson, G., \& Sarnin, P. (1994). CEOs' cognitive maps and the scope of the organization. Strategic Management Journal, 15(6), 437-457.

Champoux, J. E., \& Billsberry, J. (2012). Using moving images in management education: Technology, formats, delivery and copyright. In J. Billsberry, J. Charlesworth, \& P. Leonard (Eds.) Moving Images: Effective Teaching with Film and Television in Management, pp. 149-158. Charleston, NC: Information Age Publishing.

Clapp-Smith, R., Vogelgesang, G. R., \& Avey, J. B. (2009). Authentic Leadership and Positive Psychological Capital The Mediating Role of Trust at the Group Level of Analysis. Journal of Leadership \& Organizational Studies, 15(3), 227-240. 
Cooper, C. D., Scandura, T. A., \& Schriesheim, C. A. (2005). Looking forward but learning from our past: Potential challenges to developing authentic leadership theory and authentic leaders. The Leadership Quarterly, 16(3), 475-493.

Costas, J., \& Taheri, A. (2012). 'The return of the primal father'in postmodernity? A Lacanian analysis of authentic leadership. Organization Studies, 33(9), 11951216.

Cottrill, K., Lopez, P. D., \& Hoffman, C. C. (2014). How authentic leadership and inclusion benefit organizations. Equality, Diversity and Inclusion: An International Journal, 33(3), 275-292.

Dempsey, M., Halton, C., \& Murphy, M. (2001). Reflective learning in social work education: Scaffolding the process. Social Work Education, 20(6), 631-641.

Diddams, M., \& Chang, G. C. (2012). Only human: Exploring the nature of weakness in authentic leadership. The Leadership Quarterly, 23(3), 593-603.

Ely, R. J., Ibarra, H., \& Kolb, D. M. (2011). Taking gender Into account: Theory and design for women's leadership development programs. Academy of Management Learning \& Education, 10(3), 474-493.

Ford, J., \& Harding, N. (2011). The impossibility of the 'true self' of authentic leadership. Leadership, 7(4), 463-479.

Gardiner, R., A. (2011). Critique of the discourse of authentic leadership. International Journal of Business and Social Science, 2(15), 99-104.

Gardner, W. L., Cogliser, C. C., Davis, K. M., \& Dickens, M. P. (2011). Authentic leadership: A review of the literature and research agenda. The Leadership Quarterly, 22(6), 1120-1145.

Gardner, W. L., Avolio, B. J., Luthans, F., May, D. R., \& Walumbwa, F. O. (2005). “Can you see the real me?" A self-based model of authentic leader and follower development. The Leadership Quarterly, 16(3), 343-372.

Giallonardo, L. M., Wong, C. A., \& Iwasiw, C. L. (2010). Authentic leadership of preceptors: predictor of new graduate nurses' work engagement and job satisfaction. Journal of Nursing Management, 18(8), 993-1003.

George, W. (2003). Authentic leadership: Rediscovering the secrets to creating lasting value. San Francisco: Jossey Bass.

Hannah, S. T., Walumbwa, F. O., \& Fry, L. W. (2011). Leadership in action teams: Team leader and members' authenticity, authenticity strength, and team outcomes. Personnel Psychology, 64(3), 771-802.

Hibbert, P. (2013). Approaching reflexivity through reflection: Issues for critical management education. Journal of Management Education, 37(6), 803-827.

Hill, A. (2012). Authentic leadership needs skills to succeed. Financial Times, 27 February, 16. 
Jensen, S. M., \& Luthans, F. (2006). Entrepreneurs as authentic leaders: impact on employees' attitudes. Leadership \& Organization Development Journal, 27(8), 646-666.

Kelly, S. (2013). Towards a negative ontology of leadership. Human Relations, 67(8), 905-922.

Kernis, M. H. (2003). Toward a conceptualization of optimal self-esteem. Psychological Inquiry, 14(1), 1-26.

Kompf, M. (1993). Construing teachers' personal development: Reflections on landmark events through career mapping. In J. Calderhead \& P. Denicolo (Eds.) Research on Teacher Thinking: Understanding Professional Development, 220, 167-176.

Kore-Eda, H. (Director), Sato, S., \& Shigenobu, Y. (Producers). (1998). Wandâfuru raifu (After Life) [Motion picture]. Tokyo: TV Man Union \& Tokyo: Engine Films.

Kouzes, J. M., \& Posner, B. Z. (2002). The Leadership Challenge. San Francisco: JosseyBass.

Lawler, J. (2005). The essence of leadership? Existentialism and leadership. Leadership, $1(2), 215-231$.

Leroy, H., Anseel, F., Gardner, W. L., \& Sels, L. (2012). Authentic leadership, authentic followership, basic need satisfaction, and work role performance: A cross-level study. Journal of Management, [published online].

Leroy, H., Palanski, M. E., \& Simons, T. (2012). Authentic leadership and behavioral integrity as drivers of follower commitment and performance. Journal of Business Ethics, 107(3), 255-264.

Luthans, F., \& Avolio, B. (2003). Authentic leadership development. In K. S. Cameron, J. E. Dutton, \& R. E. Quinn (Eds.), Positive Organizational Scholarship: Foundations of a New Discipline, pp. 241-258. San Francisco: Berrett-Koehler.

May, D. R., Chan, A. Y., Hodges, T. D., \& Avolio, B. J. (2003). Developing the moral component of authentic leadership. Organizational Dynamics, 32(3), 247-260.

Neider, L. L., \& Schriesheim, C. A. (2011). The authentic leadership inventory (ALI): development and empirical tests. The Leadership Quarterly, 22(6), 1146-1164.

Nichols, T. W., \& Erakovich, R. (2013). Authentic leadership and implicit theory: a normative form of leadership? Leadership \& Organization Development Journal, 34(2), 182-195.

Northouse, P. G. (2016). Leadership: Theory and Practice. $7^{\text {th }}$ edition. Thousand Oaks, CA: Sage.

Nyberg, D., \& Sveningsson, S. (2014). Paradoxes of authentic leadership: Leader identity struggles. Leadership, 10(4), 437-455.

Petriglieri, G., Wood, J. D., \& Petriglieri, J. L. (2011). Up close and personal: Building foundations for leaders' development through the personalization of management learning. Academy of Management Learning \& Education, 10(3), 430-450. 
Rich, R. Z., \& Blake, S. (1994). Using pictures to assist in comprehension and recall. Intervention in School and Clinic, 29(5), 271-275.

Roe, K. (2014). Leadership: Practice and Perspectives. Oxford: Oxford University Press.

Sendjaya, S., Pekerti, A., Härtel, C., Hirst, G., \& Butarbutar, I. (2014). Are authentic leaders always moral? The role of Machiavellianism in the relationship between authentic leadership and morality. Journal of Business Ethics, 1-15. [published online]

Shamir, B., \& Eilam, G. (2005). "What's your story?” A life-stories approach to authentic leadership development. The Leadership Quarterly, 16(3), 395-417.

Taylor, S. S., \& Ladkin, D. (2009). Understanding arts-based methods in managerial development. Academy of Management Learning \& Education, 8(1), 55-69.

Van Buskirk, W., \& London, M. (2008). Inviting the muse into the classroom: Poetic license in management education. Journal of Management Education, 32(3), 294315.

Van Buskirk, W., \& London, M. (2012). Poetry as deep intelligence: A qualitative approach for the organizational behavior classroom. Journal of Management Education, 36(5), 636-668.

Walumbwa, F. O., Avolio, B. J., Gardner, W. L., Wernsing, T. S., \& Peterson, S. J. (2008). Authentic leadership: Development and validation of a theory-based measure. Journal of Management, 34(1), 89-126.

Walumbwa, F. O., Wang, P., Wang, H., Schaubroeck, J., \& Avolio, B. J. (2010). Psychological processes linking authentic leadership to follower behaviors. The Leadership Quarterly, 21(5), 901-914.

Weischer, A. E., Weibler, J., \& Petersen, M. (2013). "To thine own self be true": The effects of enactment and life storytelling on perceived leader authenticity. The Leadership Quarterly, 24(4), 477-495.

Wong, C. A., \& Cummings, G. G. (2009). The influence of authentic leadership behaviors on trust and work outcomes of health care staff. Journal of Leadership Studies, 3(2), 6-23.

Yukl, G. (2010). Leadership in Organizations (7th ed.). Englewood Cliffs, NJ: Prentice Hall.

Zehndorfer, E. (2013). Leadership: A Critical Introduction. London: Routledge. 


\section{Author Biographies}

Jon Billsberry is Professor in Management at Deakin University. He has served as the Editor-in-Chief of the Journal of Management Education and Chair of the Management Education and Development division of the Academy of Management. His research interests are in organizational misfit, educational innovation, and the cinematic portrayal of work.

Andrea North-Samardzic is Lecturer in Organizational Behavior at Deakin University. She has previously occupied academic roles at Monash University, LUISS Guido Carli, and the University of New South Wales. Her research interests are in implicit theories of leadership, innovative teaching techniques in management, equality and diversity, and informal learning. 